\title{
Tectona grandis, nova hospedeira de Rhizoctonia solani no Pará
}

\author{
Luiz Sebastião Poltronieri ${ }^{1}$, Jaqueline Rosemeire Verzignassi ${ }^{2}$ e Ruth Linda Benchimol ${ }^{1}$
}

${ }^{1}$ Embrapa Amazônia Oriental, Tv. Enéas Pinheiro, S/N, CEP 66095-100, Belém, PA, e-mail: poltroni@ cpatu.embrapa.br ${ }^{2}$ Embrapa Gado de Corte, Rod. BR 262, Km 4, Caixa Postal 154, CEP 79002-970, Campo Grande, MS, e-mail: jaqueline@ cnpgc.embrapa.br Autor para correspondência: Jaqueline Rosemeire Verzignassi. jaqueline@cnpgc.embrapa.br Data de chegada: 14/05/2007. Aceito para publicação em: 11/12/2007

A teca (Tectona grandis Linn. F.) é uma espécie arbórea de grande porte, nativa das florestas tropicais situadas entre $10^{\circ}$ e $25^{\circ} \mathrm{N}$ no subcontinente índico e no sudeste asiático, principalmente na Índia, Burma, Tailândia, Laos, Camboja, Vietnã e Java. A espécie tem como principais características rusticidade, rápido crescimento, facilidade de cultivo, resistência ao calor, pragas e doenças. Os primeiros frutos surgem aos cinco anos de idade. Possui madeira de excelente qualidade, de valorizada beleza, resistência e durabilidade. Há grande procura dessa espécie no mercado mundial, havendo, assim, a necessidade de produção e de material genético de boa qualidade em larga escala.

A teca é uma espécie relativamente resistente e, no Brasil, não existe registro de doenças que provocam danos econômicos aos povoamentos.

Em viveiro de mudas de espécies florestais no Município de Castanhal (PA), plantas de dois meses de idade foram encontradas apresentando lesões foliares. As lesões, inicialmente pequenas, verdes e úmidas, aumentavam de tamanho, formando áreas necróticas irregulares (Fig. 1).

As folhas apresentavam teia micélica sobre a qual microescleródios eram formados. Fragmentos de tecido lesionado foram desinfestados, transferidos para placas de Petri contendo meio de cultura batatadextrose-ágar (BDA) e mantidos sob luz fluorescente contínua a 25 ${ }^{\circ} \mathrm{C}$. Após cinco dias obtiveram-se culturas com crescimento micelial abundante, hifas espessas, ramificadas com ângulos de $90^{\circ}$. Após 15 dias, as colônias apresentaram abundante formação de microesclerócios. Verificou-se tratar de Rhizoctonia solani Kuhn (Teleomorfo: Thanatephorus cucumeris (Frank) Donk). Estudos efetuados por Kátia Nechet (Embrapa Roraima), envolvendo a coloração e contagem de núcleos e anastomose de hifas do isolado contra isolados-padrões,

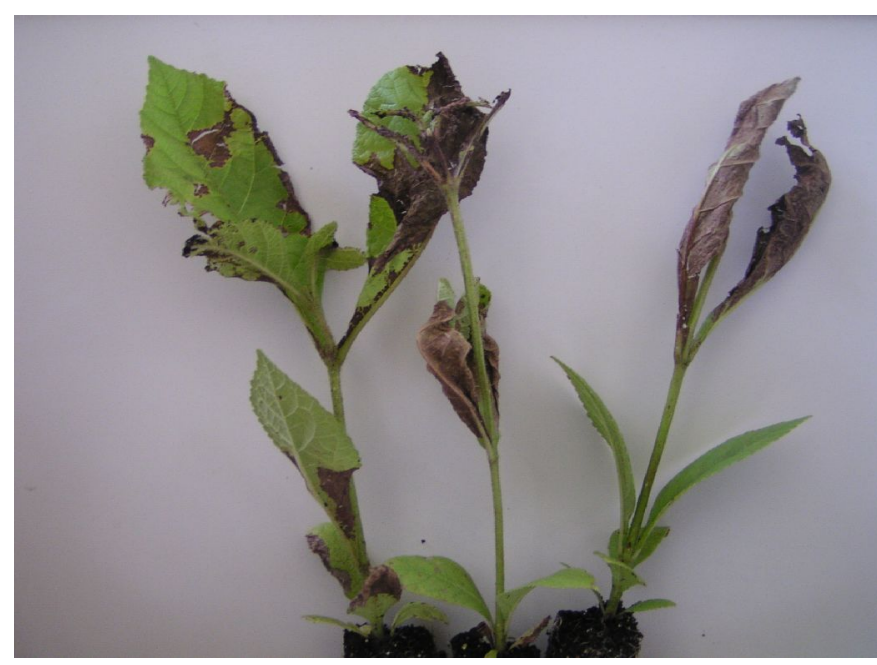

Figura 1. Mudas de teca com sintomas de queima da teia micélica, causada por Rhizoctonia solani. AG1-IA

mostraram que o mesmo é multinucleado e pertence ao grupo de anastomose AG1-IA.

Discos ( $8 \mathrm{~mm}$ de diâmetro) de cultura (5 dias de idade) foram utilizados para o teste de patogenicidade em plantas sadias de teca, com dois meses de idade. Após quatro dias, os sintomas foram reproduzidos e procedeu-se o reisolamento do patógeno, confirmandose a patogenicidade do isolado. Este é o primeiro registro de queima da teia micélica, causada por Rhizoctonia solani (Thanatephorus cucumeris) AG1-IA, em teca no Brasil e no mundo. 